\title{
The Argument of Rightness as an Element of the Discretionary Power of the Administrative Judge
}

\author{
Bartosz Wojciechowski ${ }^{1}$ (D) Marek Zirk-Sadowski ${ }^{1}$ (D)
}

Published online: 25 November 2019

(c) The Author(s) 2019

\begin{abstract}
The article concerns the situation of the judicial application of the law where the entity applying the law refers in a decision-making process to moral principles. The decision should be based on the directives of interpretation, which indicate the need for such a determination of the meaning of the applicable norms so that it remains in harmony with commonly accepted moral rules of the society. The equity (understood as rightness) has one more purpose; namely, it allows for the process of decision-making - and not just for the process of unifying the decisions-since the mere rule does not specify the algorithm of undertaking them. This rule thus assumes that it will be further specified by phronesis judge who in a given situation will determine - for the purposes of a particular decision - a hierarchy between the criteria of substantive justice "embedded" in this rule. The reference to equity (rightness) stands for the concretization of an unspecified general rule. We deal here with an indefinite general rule, the application of which is facilitated by a reference to rightness.
\end{abstract}

Keywords Rightness · Interpretation · Judicial discretion · Good faith

The full conception of interpretation of law comprises three layers. The first layer is the epistemology, assumed for the theory of interpretation. Second is the determination of the relation of the theory of interpretation to the doctrine of interpretation (ius interpretandi), manifesting itself in the legal practices acceptable by the researcher-usually judicial ones. The final layer is the construction of the theory of interpretation itself, which is in large part the result of methodological solutions adopted by the type of jurisprudence.

Marek Zirk-Sadowski

msadowski@wpia.uni.lodz.pl

Bartosz Wojciechowski

bwojciechowski@wpia.uni.lodz.pl

1 Faculty of Law and Administration, University of Lodz, Ul. Kopcinskiego 8/12, 90-232 Lodz, Poland 
In the Polish theory of interpretation, the epistemological problems are revealed in its many dimensions, though such problems are rarely revealed in the interpretative polemics, which are mostly based on intuitive and natural arguments. Meanwhile, the question of the cognition of law is closely linked with the issue of its interpretation. The structure of a cognitive act, the relationship of the entity knowing the law to the object of knowledge, and the problem of the direct knowledge of law are typical issues whose determination (sometimes unconsciously) decides on the subsequent adoption of a specific theory of interpretation. Epistemology of law is a separate issue, and even a brief analysis of such would go beyond the frames of this paper. Epistemology, or, in other words, the theory of cognition, covers such issues as the source of knowledge, the question of the role of experience in the creation of knowledge, the role of reason in cognition, the certainty of knowledge, direct knowledge of reality, and scepticism.

In their research on the interpretation of law, lawyers undertake epistemological problems but in a simplified way. It is difficult to reprove them for this. Jurisprudence is a practical science; its aim is not to conduct philosophical considerations as such, but rather to use certain philosophical solutions to create theoretical conceptual constructions that will improve the application of law, especially in solving social problems. Examples of such structures may be the issues of the existence of law and the concepts that are used to its cognition, distinctions of legal normativity, the criteria of the applicability of law, the relation of law to morality, legal liability, causation, or the understanding of law itself.

The legal practice based on positivism perceives the existence of two relatively separated discourses in law. The first is the discourse conducted in the framework of the law-making. In a very simplified way, it presents - in preliminary terms - the political interests so that it is subsequently possible, mainly in parliamentary argumentation, to differentiate the one that can be considered as the most universal for the political community. In the normative form it is recognized in categories acceptable in the state of law, since they in fact constitute a specific turning point for political discourse. The general interest, articulated in such a manner, is subsequently expressed in the legal text, the publication of which ends the process of law-making.

Generality and abstractness of the names used in it make it impossible to directly apply it to the settlement of individual and specific cases, so that in order for it to fulfil its cultural role it must be subjected to development in a subsequent discourse, which is referred to as judicial application of law. In the political dimension of this issue there is applied the principle of the separation of power, according to which on the basis of a set of such texts the judiciary freely and independently resolves conflicts among the entities subjected to the sovereign power.

In this approach to law, it quickly turned out that it is not clear whether the law as a set of norms can be known based on the direct understanding of the legal text established by the legislator or whether there opens here the field for the judiciary, which-while complementing law with the interpretative decisions-ultimately shapes it. Law, then, is not only the result of the activity of the legislative authorities but the joint undertaking of the legislative authorities, the judiciary, and the executive in the area in which it interprets law. Is it possible, therefore, to know law by directly capturing its clear meaning, or it is always necessary-when knowing 
law - to interpret it? This question has a primarily political dimension, because the answer to it determines the manner of exercising judicial power, as well as the interrelations between administration and the political sphere of the state.

Understanding, which is the essence of interpretation, requires one to constantly start anew something that may even seem obvious. It also results from temporality and historicity of the meanings. They are passed from generations and reinterpreted in the new conditions of life. It is therefore clear that the legal texts that were enacted a few 100 years ago are treated as applicable. It would be useless if we recognized that there is some objective meaning of these texts, direct and given in advance and forever, because it would be the meaning assigned to them by a certain generation of lawyers. In such case, it would be impossible to explain the historicity of law or the development of the texts of law. It is only a creative and social understanding of language that can explain this phenomenon.

This philosophy of understanding and interpretation of law undermines the objectivity of interpretation; it rejects the myth of law as an objective and external objectivity and the myth of the lawyer as an entity knowing the law externally without the possibility of influencing the normative dimension of culture, cf. [16, 24, 25]. Hermeneutics notes that law constitutes itself in the act of understanding; it is not present before the interpretation because the materialisation of law takes place only in the process of interpretation and in the course of reaching the legal settlement [16: 69ff.]. The metaphor of the hermeneutic circle aims to provide the thesis that there is no starting point when it comes to determining the meanings, and thus, as a result, each fragment of the text makes sense only if it is related to the whole situation and culture to a historical moment in which it is read. Hermeneutics, therefore, does not put forth that the text is a fetish; rather, it is only a starting point, a groundwork for a dialogue, even when it is linguistically clear.

The consequence of the current socioeconomic development and the ethical changes, as well as the changes in the worldview, is a growing role of the functional interpretation. Law is presented here as a fact of the interpretation. This, in turn, raises a lot of doubts and fears, since referring in the process of interpretation to the general objectives may in a significant way modify the meaning of the applied norm, as results from its linguistic understanding. This additionally involves the risk of granting to the interpreter an excessive freedom-or even arbitrariness-in the process of interpretation, which raises controversies, especially in those branches of law, in which the principle of legal certainty is described as fundamental. It is worth noting that while it has been rejected that there exists any meaning of the text that stems from the features intrinsically associated with the text itself, this impression arises only by the fact that the text recalls the elements of the social and cultural context repeatable to a given interpretive community. This means that although the interpretation depends entirely on this context, it cannot be said that it is subjective and arbitrary.

It is emphasised in the literature and jurisprudence that the tax law, in particular, should be created in a precise and possibly definite manner and that the so-called autonomous model should be characteristic for its creation. In this model, the most important values are legality and legal security, including the guarantees of the fundamental human rights. There dominates the argumentative procedure of discussing 
law and the idea of formal justice. As a result, what should form the basis of this field of law in this approach are largely specified and not textually open provisions. Tax law should be the most clear and predictable area of law. It is worth noting that the representatives of this science of law very clearly manifest the practical significance of the limits of the scope of interpretation. It is particularly visible in respect of the representatives of the science of tax law. ${ }^{1}$ The tax law, as imposing certain financial obligations on the citizens and other entities, should have to the greatest extent closed character so as not to facilitate the extension of these duties.

It should therefore be remembered that strictly following the functional interpretation exclusively may cause undesirable need to take into account the individuality and heterogeneity of each case, opposing at the same time an uncritical assimilation of the existing ethical systems or meanings and consequently introducing the element of uncertainty to the jurisprudence. In the context of the tax law, there can be observed the transition to an autonomous model. In the autonomous legal order, the legitimization of the legality as a kind of cultural value is carried out mainly by guaranteeing the right to protection of certain fundamental values. Autonomous values of law are, in particular, human rights and the institutions of the democratic rule of law. At this point, we therefore deal with the axiological context of determining the limits of interpretation. Formal justice is a requirement for the consistent application of general rules, resulting in the uniformity of jurisprudence and legal certainty. According to an alternative and equivalent definition, justice is a requirement of equal treatment of the equal persons in the light of a particular rule, as well as a requirement of an unequal treatment of the unequal people in the light of this rule. In turn, the validity (rightness) is a certain type of justice whose normative content can be reduced to the requirement of a full ethical adequacy of decisions to a particular situation. ${ }^{2}$

The supporters of freedom (understood in procedural terms), as well as of formal justice, usually advocate narrow limits of the interpretation of law, considering as acceptable only the linguistic and systemic interpretation. Meanwhile, the supporters of prosperity and equity (rightness) usually support wide limits of the interpretation, considering as admissible - in addition to linguistic and systemic interpretationthe functional interpretation in its various forms (e.g. teleological and axiological), because such an interpretation enables the realization of goals that go somewhat beyond the content of the rules (set by the contents of the rule itself and by the fact of this rule being a part of a system of rules). The axiological dispute taking place on the second level does not have visibly differentiating consequences in the context of the debate about the limits of interpretation, because both the advocates of social justice, as well as the advocates of welfare, typically vote for wide limits of interpretation of law, though the proponents of social justice usually define these limits even

\footnotetext{
${ }^{1}$ In particular, R. Mastalski stresses that "the linguistic interpretation (...) outlines its limits in the framework of the possible meaning of the words contained in the legal text". [13: 102]. Similarly, B. Brzeziński stresses this fact, when writing that "(...) the meaning of the legal text is the absolute limit of interpretation" [4: 60].

${ }^{2}$ This rather vague definition is clarified in point 2 .
} 
wider than the proponents of prosperity. The very schematic characteristic of the viewpoints listed above can be summarized in the following words: the advocates of freedom and formal justice usually advocate the so-called ideology of a bound court decision, whereas the advocates of social justice, prosperity, and rightness usually advocate the so-called ideology of a discretionary court decision. As follows from the foregoing, the argumentation in favour of a particular position in the dispute over the limits of the interpretation of law requires in-depth axiological analysis.

At this level there take place discussions related to, among other things, the thesis of the need to combine the legal and the moral discourse, cf. [5]. It is worth noting that the relationship between morality and law are twofold. Namely, they may be of a classifying nature (morality is the criterion for recognizing a given norm to be valid) or have the character of eligibility (morality is the criterion indicating the defective legal regulations) [3: 291]. In this context-according to Robert Alexy"a judge who chose' a morally mistaken interpretation in a case in which the positive law allows as well for a morally correct interpretation would not be making a legally perfect decision" [3: 295]. In situations where the correct reading of the legal norm requires taking into account its extra-linguistic meaning, we deal with a socalled hard case.

A hard case takes place, in most general terms, when the judge does not have an unambiguous norm at his disposal that was created by a certain authority, but there are also cases of difficulties in decision-making arising from the lack of consensus among lawyers. ${ }^{3}$ In other words, the applied legal provision is vague, and the rules of the legal methodology do not lead directly (in binding way) to an unambiguous result. To put it differently, in hard cases, it is not possible to apply the valid law in a "mechanical" (syllogistic) manner, but the judge refers to other prescriptive statements, such as moral norms or custom.

In some situations, the judge in the process of reading a legal norm or at the stage of the subsumption encounters the norms that directly refer to social evaluations and rules, containing such statements as, for example, "rightness" ("equity") or "justice". The adoption of a certain normative theory of interpretation (static or dynamic) influences the fact whether the interpreter will look for moral judgments, which the legislator "had in mind" when creating a particular norm, or whether he will take into consideration the moral judgments binding at the time of undertaking the interpretation of a given norm [21: 5]. In a situation where the entity applying the law refers in a decision-making process to moral principles, it should be based on the directives of interpretation, which indicate the need for such a determination of the meaning of the applicable norms so that it remains in harmony (or at least is not in contradiction) with commonly accepted moral rules of the society. The equity

\footnotetext{
${ }^{3}$ Cf. R. Dworkin [8: 13]. "(...) in which no explicit rule in the rule book firmly decides the case either way." Dworkin in a consistent way marks his differentiation between hard and easy cases as merely the means to present his vision in [9: 351]. "The distinction I relied upon is just an expository device (...)." See also R. Alexy [2: 25]. Dworkin opposes the concept of "hard cases" with the phrase "easy cases" and "simple cases", defining them respectively as "unoriginal judicial decisions that merely enforce the clear terms of some plainly valid statute" or "cases in which some statute exactly in point unambiguously dictates a particular result”. Cf. R. Dworkin [9: 106].
} 
(understood as rightness) has one more purpose; namely, it allows for the process of decision-making - and not just for the process of unifying the decisions-since the mere rule does not specify the algorithm of undertaking them. This rule thus assumes that it will be further specified by phronesis judge who in a given situation will determine - for the purposes of a particular decision - a hierarchy between the criteria of substantive justice "embedded" in this rule. The reference to equity (rightness) stands for the concretization of an unspecified general rule. We deal here with an indefinite general rule, the application of which is facilitated by a reference to rightness. Equity understood as rightness is therefore, in the latter case, a somehow indirect sufficient condition ${ }^{4}$ for achieving the formal justice, which, as mentioned, relies on the consistent application of general rules.

Referring to moral principles in order to settle a hard case is not accepted uncritically; on the contrary, this issue is subject to-especially by philosophers of law-a detailed analysis. David Lyons who states that in the event when the directions resulting from the applicable law are not sufficient, the court not only can but should issue a judgment referring to the moral principles. ${ }^{5}$ The requirement to resolve such issues is, in fact, apparent from the general procedural prescription and assumption that the judgment should be issued in a morally responsible manner. This position is mainly approved by the representatives of the so-called sophisticated legal positivism. The representatives of this version of positivism believe that the court may even be obliged to sometimes appeal to the moral arguments in order to issue the correct decision [15: 447-448]. Such an assumption becomes particularly relevant when the basis for the judgment includes the constitution, the bill of rights, and other compilations of laws. Such acts of law containing a direct reference to the fundamental rights and freedoms seem to encourage the courts to apply directly in the decision-making process the arguments based on the moral principles and even on the sense of morality itself (see, e.g. [18]). Similarly, Ronald Dworkin notes that the role of the judge is reaching the correct decision by means of the hermeneutic dialogue, taking into account the different elements that comprise the current image of law, including, inter alia, social morality underlying law. ${ }^{6}$ In the community model assumed by this author, there is therefore the assumption of moral ties and coherence of the system of principles of all members of a given political community.

In this context, Lech Morawski states that in the course of interpretation, the need to take into account the prevailing moral beliefs in a given society allows for the formulation of the following rule: "When interpreting the legal provisions there must be taken into account the commonly accepted moral norms, principles of justice

\footnotetext{
4 Though certainly not as a prerequisite, since clarifying the rules may also take place in the "unjust (unrighteous)" way.

5 D. Lyons [12: 86]. Lyons points out further, however, [12: 98-99] that if difficult cases can be resolved only by referring to the existing law, those decisions will mainly reflect the advantages and the disadvantages of this law. The moral principles can help to shape the law, but one cannot assume that they do so more effectively than anything else.

${ }^{6}$ R. Dworkin [7]:116, 344ff]. Dworkin writes, among other things, that the judges, when referring to moral principles, have in mind those principles that are behind the institutions and the laws of a given society, thus playing an important role in the coherent theory of law described by him.
} 
and equity" [14: 220]. In the same aspect, Jerzy Wróblewski differentiates two main ways of formulating directives of interpretation - a positive approach and a negative approach [21: 10-11]. According to this author, in the positive approach the following rule is applied: "If there are acceptable different meanings of a legal norm, then one should choose that meaning in which the norm is most consistent with the accepted moral evaluations", while in the negative approach there applies the following rule: "One cannot determine the meaning of the norm in such a way that it is inconsistent (in contradiction) with the accepted moral evaluations". With regard to the functional interpretation, it can be seen that it applies to the implementation of these values, which are treated as objectives, as well as those that determine the implementation of the objectives, reconstructed as the objectives attributed to a specific legal regulation.

Wherever the judge does not approach the process of applying law in a strictly formalized and bound manner, there comes to the fore the discretionary power of the judge. In such an event the judge is not faced with the task of carrying out a simple, rational subsumption; rather, he is authorized to balance between a greater number of alternatives-namely, he must settle substantively. The judge can then decide between two contradictory decisions (e.g., to grant or not to grant a permit), or in a disjunction there is provided a larger number of acceptable solutions. The concept of "the discretion" is also used in the sense of "evaluation" when it comes to a valuating adjudication constituting the nature of judicial discretion and the margin of freedom granted to the judge. In contemporary Anglo-Saxon literature devoted to the issue of "judicial discretion", it is stressed that this issue should be discussed in a broader context that would allow the semantic and epistemic aspects to be taken into consideration, cf. [1, 10, 17: 14ff., 19, 20]. This allows for analysing in this context such issues as the knowledge of the social phenomena, the status of social ontology, and the relationship between law and language.

From this point of view, the judicial discretion extends to both the horizontal and the vertical sphere of the judicial activity. This scope includes not only the various fields of legal norms, which provide the judge with the freedom to adjudicate, but also the varying degrees of legal qualification of the individual cases. Judicial freedom applies to the cognitive process, to the assessment of the facts, to the interpretation of legal norms, to the determination of their mutual relationship, and sometimes even to the law-making process itself. Judicial discretion applies to every type of judicial freedom, regardless of whether its origins can be traced back to the statutory authorisation or whether it is the result of its adoption by the judiciary in a "praeter or contra legem" manner during the settlement of the individual case, which was not precisely enough defined in the statute.

Classically, the issue of judicial discretion in broad terms is associated with vague legal concepts and general clauses. The need in legal texts to apply the vague terms means that the legislator, sometimes due to the law being enacted for a distant future, must oscillate between the Scylla of the legal certainty and the Charybdis of its flexibility. Vague legal concepts appear in all areas of law. Under the concept "vague term", there shall be understood that the concept-the content and the scope of which is uncertain-does not fix immediately and fully all the elements of the hypothesis and the disposal, as opposed to a specific concept, whose hypothesis and 
disposition determine in a complete and reliable manner all the elements of the state of facts. ${ }^{7}$ As follows from the analysis of the structure of concepts, each abstract regulation is more or less vague and therefore requires a specification and interpretation. Interpretation and subsumption are also required in respect of "specific" concepts, namely those filled with content, that are clear and distinguishable from other norms and legal institutions.

J. Wróblewski believes that it is within the sphere of judicial discretion to choose the type of evaluation the judge must undertake in order to select one of the possible consequences. The example that the author takes is the clause of compliance with the principles of social coexistence as a directive of the choice of the consequences. The author indicates, moreover, that in such a case, the judicial practice establishes the legal consequences from the point of view of "social sense of justice" or "sense of rightness" [23: 192].

In this paper, we would like to use another very characteristic example, namely the concept of "good faith" on the basis of the interpretation of art. $86 \S 1$ and 2 point 1 letter a) of the Act of 11 March 2004 Tax on goods and services (i.e. Journal of Laws of 2011, No. 177, item 1054, as amended), in conjunction with art. 167 paragraph 2 of the Council Directive 2006/112/EC of 28 November 2006 on the common system of value added tax (Official Journal of the EU, series L 2006, No. $347 / 1$, referred to hereinafter as "Directive 2006/112/EC"). The taxpayer may exercise the right to deduct the tax on goods and services provided for in this Act in respect of the supply of goods or services by another taxpayer only in relation to the tax arising from an invoice that documents the actual activity carried out by the issuer of the invoice that was subject to this tax. Where the amount indicated as the tax results only from the invoice-which does not document the actual event giving rise to the tax duty of its issuer-such an invoice does not give the right to deduct the amount shown in it. In such case, the fact of the buyer holding an invoice issued by the vendor constitutes only a formal condition for exercising that power, which is not a per se entitlement to a tax deduction, if it is not accompanied by complying with the condition of performing an actual activity that results in the tax liability of the issuer of the invoice for its performance for the buyer.

In reference to those provisions, the Court of Justice of the European Union pointed out the need to take into consideration the institution referred to as good faith (or due diligence) of the taxpayer. This institution has the character of a new construction or a postulate that in this aspect requires a reference to the argument of rightness in the course of interpretation and subsumption. Undoubtedly, the concept in question introduces a relatively wide range of judicial discretion in deciding a particular case by referring to the taxpayer's good faith. On the one hand, this phrase has a character of a general clause, and on the other hand, the phrase has the character of evaluation, since the Court of Justice refers to the taxpayer's due diligence when assessing the criterion for whether this condition was met. In addition, the

\footnotetext{
7 Such a strict distinction between vagueness and blurred concepts is not necessary from the point of view of this article. Therefore, I will use a broad understanding of vague concepts, including also blurred concepts.
} 
discretion of a judge in this case is enhanced by the traditional phrase found in the judgments of the CJEU: "What should be examined by the referring court".

In its case law, the CJEU has repeatedly noticed that the struggle against tax evasion, tax avoidance, and possible abuse is an objective recognized and encouraged by the Sixth Directive (now Directive 112$)^{8}$ (). Taxpayers cannot rely on the EU norms for fraudulent and abusive purposes (see the CJEU judgments on. ${ }^{9}$ The national administrative and judicial authorities should deny the right to apply deduction if it is proved on the basis of objective evidence that the exercise of this right would be associated with unfair objectives, crime, or abuse. ${ }^{10}$ In addition, the taxpayer who knew or should have known that by purchasing goods or services he was involved in the transaction, constituting an element of an offence in the area of VAT, should be-from the point of view of the Sixth Directive-considered as an accomplice in the crime. The taxpayer is considered an accomplice regardless of whether he receives benefits from the further sale of those goods or services made in the framework of his taxable transactions later in his trade ${ }^{11}$ and irrespective of whether that transaction meets the objective criteria underlying the concept of the supply of goods that have been carried out by a taxpayer acting as such and the concept of economic activity. ${ }^{12}$

It is up to the national courts and the tax authorities to undertake, in accordance with the rules laid down in the national law, the global assessment of the overall data and facts of the case in order to determine whether an economic entity can exercise the right to deduct tax in connection with the disputed supply of goods. ${ }^{13}$ The determination of the actions, which in a particular case can reasonably be expected from a taxpayer who intends to exercise the right to VAT deduction in order to ensure that the transactions performed by him do not involve the commission of a crime by the operator at an earlier stage of the trade, depends primarily on all the circumstances of the analysed event. ${ }^{14}$ If there are grounds to suspect an irregularity or crime, a circumspect trader should, depending on the circumstances of a particular case, obtain information about the entity from which it intends to purchase goods or services in order to ascertain its credibility. ${ }^{15}$ The Court held in this regard that the tax authorities cannot generally require taxpayers wishing to exercise the right to deduct VAT to investigate whether the issuer of the invoice for the goods or services for which the deduction is concerned holds the goods that are the subject of the transaction, whether he is able to deliver them, and whether he complies with the obligation to file tax return and pay VAT in order to ensure that the operators in the earlier stages

\footnotetext{
8 See the CJEU judgments [28: para. 76], [31: para. 54] and [30: para. 71].

9 See the CJEU judgments [26: para. 20], [27: para. 33] and [29: para. 32].

10 Among others, see the CJEU judgments [32: para. 42] and [34: para. 37].

11 See the CJEU judgment [32: para. 46] and [34: para. 39].

12 Cf. the CJEU judgment [31: para. 51-53, 56-59].

13 See the similar CJEU judgments [33: para. 53] and [34: para. 32].

14 See the CJEU judgment [32: para. 59], as well as the rulings of the CJEU [36: para. 39] and [37: para. 37].

15 The CJEU judgment [32: para. 60]; the CJEU ruling [36: para. 40] [37: para. 38].
} 
of the trade do not commit irregularities or crimes or that the taxpayer should hold the relevant documents to confirm this fact. ${ }^{16}$

Therefore, in a given situation, when deciding whether there was a taxable transaction, the court on which the tax authority relies-particular on the irregularities committed by the issuer of the invoice-should ensure that the assessment of the evidence does not undermine the sense of the case-law in respect of good faith and does not indirectly force the invoice recipient to verify his contractor, which essentially does not constitute his duties. ${ }^{17}$ However, if the documents submitted by the recipient of the disputed invoices also contained irregularities, or if a particular delivery was associated with other irregularities which might have been noticed by the recipient, this constitutes a circumstance that should be taken into account in the overall assessment undertaken by the national court. ${ }^{18}$ This irregularity may, in particular, result from the fact that the nature of the actually supplied goods does not correspond to the nature of the goods specified in the invoice, in order to fulfil the obligation contained in art. 22 paragraph 3 point b) of the Sixth Directive, in the wording resulting from its art. $28 \mathrm{~h}$.

As a general rule, it can be reasonably required that the taxpayer, who intends to exercise the right to VAT deduction, ensure that the nature of the goods delivered corresponds to the nature of the goods for which the invoice was issued. ${ }^{19}$ The Court, in fact, stated that the Sixth Directive must be interpreted in such a manner that it opposes the taxpayer being denied the right to deduct VAT due or paid in respect of goods received by him on the basis that, given the offence or the irregularities committed by the issuer of the invoice relating to this delivery, it is considered that it was not actually made by the said issuer, unless it is demonstrated on the basis of objective evidence-without requiring the taxpayer to undertake verifying activities (which are not his duty) - that the taxpayer knew or should have known that the said delivery was associated with VAT offence. ${ }^{20}$

What is of utmost importance in this aspect is the judgment of the Court of Justice of the European Union issued on 22 October 2015 on Stehcemp sp. j. Florian Stefanek, Janina Stefanek, Jarosław Stefanek (C-277/14), in which it referred to the fundamental issue in the common VAT system related to the right of a taxpayer to deduct input tax on transactions treated as "suspicious". In this judgment, the Court held the following:

“The provisions of the Sixth Council Directive 77/388/EEC of 17 May 1977 on the harmonization of the laws of the Member States relating to turnover taxes-common system of value added tax: uniform basis of tax assessment, as amended by Directive 2002/38/EC of 7 May 2002, must be interpreted as

\footnotetext{
16 See the CJEU judgments [32: para. 61], [35: para. 61]; the CJEU ruling [36: para. 41] and [37: para. 39].

17 See the CJEU judgment [35: para. 62]; as well as the abovementioned rulings [36: para. 42] and [37: para. 40].

18 See the CJEU judgment [35: para 63], and the CJEU decisions [36: para. 43] and [37: para. 41].

19 The CJEU ruling [37: para. 42].

20 The CJEU ruling [37: para. 43].
} 
meaning that they preclude the national legislation, such as in the main proceedings, which denies the taxpayer the right to deduct the value added tax due or paid on the goods supplied to him, due to the fact that the invoice was issued by an entity that in the light of the criteria laid down by those provisions must be regarded as non-existing entity and that it is impossible to establish the identity of the actual supplier of the goods, unless it is demonstrated in the light of objective evidence, and without requiring the taxpayer to make arrangements to which it is not required that this taxpayer knew or should have known that this delivery was associated with a criminal offence in respect of value added tax, which should be examined by the referring court."

Although this judgment proved to be beneficial for the taxpayer, it does not solve completely the problem of the taxpayers whose providers turn out to be fraudsters. The problem raised in this judgment relates to the increasingly common situation where the taxpayer is denied the right to deduct input value added tax due to the fact that his contractor (supplier, the issuer of the invoice) participates in tax evasion (e.g. by issuing the so-called "blank invoices") or by accepting the role of fictitious companies, whose function is reduced to only being a seller on the issued invoice. Consequently, the VAT due is not paid, and the actual and alleged seller simply disappears, often in inexplicable circumstances. In such cases, the tax authorities seek to compensate for a depleted due amount of the tax by denying the right to deduct input VAT on the part of the purchaser. It is indeed the place where the aforementioned good faith plays a crucial role. In a number of the CJEU judgments, the Court stressed that the right to deduct input tax may depend on the existence of the taxpayer's good faith and him acting with due diligence in connection with carrying out the transaction. However, this raises a question: What should be understood as the taxpayer's good faith? What actions should be undertaken by the taxpayer so that the authorities could assume that this taxpayer actually acted with due diligence when verifying his supplier?

Unfortunately, there is no clear answer to these questions. The Court, in its judgment in the Case C-277/14, adopted the viewpoint that the taxpayer cannot be required to perform the arrangements to which he is not obliged (by the applicable provisions), yet the court at the same time pointed out that the determination of the actions that can-in a particular case-be reasonably expected from the taxpayer (who intends to exercise the right to VAT deduction) primarily depends on the circumstances of the analysed case. In other words, in any case, the good faith should be approached individually. This is extremely important, because, as pointed out by the CJEU, if the taxpayer knew or should have known that through the purchase of goods he was involved in the transaction related to the VAT offence, he should be considered to be involved in this offence, regardless of whether he achieves benefit from the resale of the goods or the use of the services within the taxable transactions undertaken by him at a later stage of the trade.

The above judgments of the CJEU resulted in interpretative difficulties on the basis of the Polish national law. The latter made it so that the main focus in tax disputes concerning the right to VAT deduction was placed only on the determination of good (or bad) faith of the taxpayer, while omitting in the course of the legal 
interpretation the importance of other provisions indicating the conditions of implementing the right to VAT deduction.

In the above case law, the concept of good faith has a vague character, and it is a reference to the famous words of Celsus: "Ius est ars boni et aequi". The vagueness or blurriness of the concepts contained in the provisions of the EU law is often a result of their economic connotations, which also supports the shift of the importance-in the course of their interpretation-from purely linguistic argumentations to functional arguments. ${ }^{21}$ It must never be forgotten that the EU law was created with the intention of establishing a European free market based on four freedoms: the free movement of goods, services, labour and capital. The analysis of the case law shows that the Court of Justice is trying, almost every time, to refer to the objectives and functions. Confronting the linguistic arguments with the functional one is thus a kind of a natural part of the process of the interpretation of EU law. An illustration of this position is presented in the judgments in Humblet [38] ("... it is not sufficient for the Court to adopt the literal interpretation and it is considered necessary to verify that this interpretation is confirmed by other criteria, in particular by the common intention of the High Contracting Parties and the ratio legis") or Stauder [39] ("where the decision is addressed to all Member States, the need for a uniform application and, at the same time, a uniform interpretation makes it impossible to take into account only one [linguistic] version of the text, but it requires that the interpretation was made both on the basis of the intentions of the creator [of the provision], and of the goal that he wishes to achieve...").

The interpretation of the term "good faith" should therefore also take into account that condition. The literature points to the two basic functions of good faith. Firstly, good faith fulfils a protective function, acting sui generis as a guarantee for the security of civil law transactions. Secondly, good faith, both in the objective term, as well as the subjective term, provides for a presence of the element of rightness in the positive law. When referring to the latter function, it should be indicated that the good faith serves as a criterion for assessing the compatibility of the operations of the party to the legal relation (of the contractor, or taxpayer) with the standard required by law.

A certain guide for interpreting the phrase "good faith" may be provided by the case law of civil courts. The latter formulated the following understanding of "good faith":

1. Good faith is a fact of the character of a mental or intellectual state, consisting in a justified ignorance of a particular entity of the existence of specific legal states; in particular, it is an erroneous conviction that there have been granted specific rights or that there exists a specific legal relation. The opposite of good faith is bad faith, which takes place when a particular entity knows (is aware) that the

\footnotetext{
${ }^{21}$ It should be, at the same time, noted that in fact the application of the functional rule, overriding the current linguistic meaning, consists in broadening the current set of possible linguistic meanings with an additional linguistic meaning that covers by its scope the functional arguments (teleological ones or those concerning rightness).
} 
specific right, legal relation, or legal situation do not exist, or when a particular entity does not know but should be considered that it would have known if-in the particular circumstances-it had acted reasonably, with due diligence, and in accordance with the principles of social coexistence (cf. [40]);

2. Good faith of the purchaser is expressed in his conviction-justified by specific circumstances - that the seller is entitled to dispose of the particular thing, while the good faith of the purchaser is excluded by the lack of awareness, caused by negligence, that the seller is an unauthorised person [41];

3. Good faith stands for the mental state of a person, consisting in a justified belief that this person is entitled to certain rights. On the other hand, a person is in bad faith when he is relying on such a right or a legal relation while knowing, or at least under the circumstances of the case should know, that these rights do not exist [42];

4. Good faith is a state of consciousness of a particular person excluding the possibility of accusing this person of reprehensible conduct (bad faith);

5. Good faith in the objective sense stands for an objective measure of one's behaviour - as the assessment of this behaviour as appropriate-from the point of view of the ethical norms generally accepted in the trade.

Based on the provided examples, one can make certain generalizing conclusions, namely, that the principles that the judge should take into account are most often of evaluating nature and are formulated in the abstract manner, which allows them to cover all potential situations, and points out what choice must be made, in a very general way. Undoubtedly, they have the character of a reference, ordering to take into account the specific arguments of rightness. J. Wróblewski notes that such directives of the choice of the consequences provide that there shall be selected the settlement which is "fair", "good", "corresponding to the principles of morality", or "in accordance with the rules of natural law", referring thereby to the extra-legal values. The author points out that in a situation of such discretion of decision-making process, there must be distinguished two points of view: legal and descriptive, as well as theoretical [22: 243, 250]. From a legal point of view, we cannot talk about limiting the freedom of the judge, because by definition it is placed outside the scope in which certain laws govern the choice. However, from the descriptive and theoretical point of view, it should be stated that the freedom of the judge is limited to the extent that the judge feels bound by the prevailing ideology and to the extent in which this ideology provides him with specific directives. Descriptive and theoretical points of view require justification of the selected legal consequences based on instrumentally or thetically relativized assessment.

The judge should always choose such a solution that will respect the claims to accuracy, rightness, justice, and justifiability of the settlement. In other words, the court—when issuing a judgment based on rightness or common sense-seeks for support, for example, in general legal principles contained in the constitution. The decision issued by the judge should be juridically linked; therefore, he cannot act in an arbitrary manner. It should be emphasized at this point that the open criteria, such as "good faith", affect the manner of determining the content of the objective pursued and participate in reading (reconstructing) the normative basis for the 
settlement while fulfilling both the role of verifying the result of the interpretation achieved by other methods of interpretation and possibly a corrective function. What can therefore be observed is an increasing importance of functional rules, which entails the need to take into account in the process of interpretation the effects of the operation of the reconstructed norm and a reference to a certain sociological or psychological knowledge [11: 331]. It also becomes important to determine the argumentative and interpretative power of the axiological elements found in the general clauses of reference, which can be transformed-from the rules that verify and correct the result of the linguistic interpretation-to the basic rules, applied equally to the linguistic or systemic rules [11: 327]. It should be remembered that the reference to the functional directives within each process of interpretation-and especially in the situation when it comes to overriding linguistic limits of interpretation and referring to a different meaning than that which is included in the current linguistic meanings - requires a very meticulous reconstruction of certain values and clear wording of the functional directive of interpretation that refers thereto (for more on this topic see [6]).

Funding Article prepared within the framework of the Grant of the National Science Centre No. DEC-2015/19/B/HS5/03114.

Open Access This article is distributed under the terms of the Creative Commons Attribution 4.0 International License (http://creativecommons.org/licenses/by/4.0/), which permits unrestricted use, distribution, and reproduction in any medium, provided you give appropriate credit to the original author(s) and the source, provide a link to the Creative Commons license, and indicate if changes were made.

\section{References}

1. Andreoni, James, and Madoff, Ray D. 2008. The role of judicial discretion in dispute settlement. In Boston College Law School Legal Studies Research Paper, 151.

2. Alexy, Robert. 1992. Begriff und Geltung des Rechts. Freiburg-München: Alber.

3. Alexy, Robert. 2008. On the concept and the nature of law, In Ratio Juris 21(3).

4. Brzeziński, Bogumił. 2008. Podstawy wykładni prawa podatkowego. Gdańsk: Ośrodek Doradztwa i Doskonalenia Kadr.

5. Cern, Karolina M., and Bartosz Wojciechowski. 2013. Postmetaphysical approach to moral autonomy and justification of the thesis of the necessary relations between the legal and moral discourse. In Legal Rules, Moral Norms and Democratic Principles, ed. Bartosz Wojciechowski, Piotr W. Juchacz, and Karolina M. Cern, 11-43. Frankfurt am Main: Peter Lang.

6. Choduń, Agnieszka, and Zieliński, Maciej. 2009. Aspekty granic wykładni prawa. In Księga jubileuszowa Profesora Ryszarda Mastalskiego. Stanowienie i stosowanie prawa podatkowego, ed. Wiesława Miemiec. Wrocław.

7. Dworkin, Ronald. 1978. Taking rights seriously. Cambridge, Massachusetts: Harvard University Press.

8. Dworkin, Ronald. 1985. A matter of principle. Cambridge: Harvard University Press.

9. Dworkin, Ronald. 1986. Law's empire. London: Fontana Press.

10. Galligan, Denis James. 1986. Discretionary powers: A Legal Study of official discretion. Oxford: Clarendon Press.

11. Leszczyński, Leszek, Bartosz Wojciechowski, and Marek Zirk-Sadowski. 2012. Wyktadnia w prawie administracyjnym. Warszawa: C.H. Beck. 
12. Lyons, David. 1984. Ethics and the rule of law. Cambridge: Cambridge University Press.

13. Mastalski, Ryszard. 2008. Stosowanie prawa podatkowego. Warszawa: Wolters Kluwer Polska.

14. Morawski, Lech. 2002. Wykładnia w Orzecznictwie Sadów. Komentarz. Toruń: TNOiK.

15. Shiner, R.A. 2000. Law and morality. In A companion to philosophy of law and legal theory, ed. Dennis Patterson. Oxford: Wiley-Blackwell.

16. Stelmach, Jerzy. 1995. Współczesna Filozofia Interpretacji Prawniczej, 2nd ed. Kraków: Wydawnictwo Uniwersytetu Jagiellońskiego.

17. Vila, Marisa Iglesias. 2000. Facing judicial discretion. Legal knowledge and right answers revisited. Dordrecht: Spring.

18. Waluchow, W.J. 1994. Inclusive legal positivism. Oxford: Clarendon Press.

19. Wiklund, Ola (ed.). 2003. Judicial Discretion in European Perspective. Stockholm: Norstedts Juridik: Kluwer Law International.

20. Wojciechowski, Bartosz. 2004. Dyskrecjonalność Sędziowska. Studium Teoretycznoprawne. Toruń: Adam Marszałek.

21. Wróblewski, Jerzy. 1961. Oceny i normy moralne w wykładni prawa. In Scientific papers of the University of Łódź. Humanities and social science: I(22).

22. Wróblewski, Jerzy. 1988. Sadowe stosowanie prawa. Warszawa: PWN.

23. Wróblewski, Jerzy. 1992. The judicial application of law. Dordrecht: Springer.

24. Zirk-Sadowski, Marek. 1982. Hermeneutyka a problemy filozofii prawa In Legal-economic studies: XXVIII.

25. Zirk-Sadowski, Marek. 1985. Democracy as hermeneutics. Archiv fur rechts- und Sozialphilosphie: LXXI/h 2: 159-172.

\section{Court of Justice of the European Union (CJEU) Judgments and Rulings}

26. Alexandros Kefalas et al., C-367/96, EU:C:1998:222.

27. Diamantis, C-373/97, EU:C:2000:150.

28. Gemeente Leusden and Holin Groep BV, C-487/01 and C-7/02, EU:C:2004:263.

29. Fini H, C-32/03, EU:C:2005:128.

30. Halifax plc et al., C-255/02, EU:C:2006:121.

31. Axel Kittel and Recolta Recycling SPRL, C-439/04 and C 440/04, EU:C:2006:446.

32. Mahagében Kft and Dávid, C-80/11 and C-142/11, EU:C:2012:373.

33. Mecsek Gabona, C-273/11, EU:C:2012:547.

34. Bonik EOOD, EU:C:2012:774.

35. ŁWK-56 EOOD, C-643/11, EU:C:2013:55.

36. Forvards V, EU:C:2013:125.

37. Jagiełł, EU:C:2014:184.

\section{European Court}

38. Judgment of the Court of 16 December 1960.- Jean-E. Humblet v Belgian State.-Case 6/60.

39. Judgment of the Court of 12 November 1969.-Erich Stauder v City of Ulm-Sozialamt.-Reference for a preliminary ruling: Verwaltungsgericht Stuttgart-Germany.-Case 29-69.

\section{The Polish Supreme Court}

40. The Supreme Court ruling of 14 April 1956, III CR 810/55, OSN 1956, item 117.

41. Judgment of the Supreme Court dated 16 June 1998, case reference number I CKN 753/97.

42. The ruling of the Supreme Court dated 21 March 2013, case reference number II CSK 495/12.

Publisher's Note Springer Nature remains neutral with regard to jurisdictional claims in published maps and institutional affiliations. 